\title{
Agricultural Input Subsidies in Pakistan: Nature and Impact
}

\author{
M. GHAFFAR CHAUDHRY and SHAMIM A. SAHIBZADA
}

\section{INTRODUCTION}

Pakistan has a history of subsidising agricultural inputs. Although none of the agricultural inputs were subsidised during the early 1950s, the process was initiated in the second half of the decade by subsidising chemical fertilisers in order to popularise their use [Niaz (1984)]. The list of subsidised inputs and the rate structure of the subsidies were expanded considerably throughout the Sixties. Towards the end of the Sixties, it was noted that almost all the agricultural inputs including fertilisers, insecticides, seeds, irrigation water, tubewell installations, and the operation and purchase of tractors and tractor-related equipment were subsidised in one form or another [Aresvik (1967) and Kuhnen (1989)]. In the 1970s, some curtailment of subsidies occurred as a result of input price increases which followed the worldwide recession, a major oil shock, the credit crunch, the war with India, and the consequent steep devaluation of Pakistani Rupee [Chaudhry (1982)]. Although the subsidies had survived the onslaught of the Seventies and tended to persist on most inputs, the government became totally committed to their removal beginning with the 1980s, under pressures from the IMF and the World Bank [Government of Pakistan (1980)]. As a consequence, there was a total withdrawal of subsidy from seeds, insecticides, tubewells, and tractors. A phased-out withdrawal of fertiliser subsidy, culminating in 1984-85 in the case of nitrogenous fertilisers and in 1989-90 in the case of phosphatic and potash fertilisers, was also to be undertaken [World Bank (1986)].

The purpose of the present paper is to highlight the progress of withdrawal of input subsidies in Pakistan, to study the nature of the input subsidies and possibly analyse the impact of the withdrawal of subsidies on the farm sector. Needless to add that the study is also intended to make policy recommendations on the various aspects of subsidy withdrawal.

\section{THE NATURE OF SUBSIDIES IN AGRICULTURE}

The emphasis on the withdrawal of subsidies from agricultural inputs has varied with the nature of subsidies, the accrual of their benefits to specific classes and

M. Ghaffar Chaudhry is Joint Director and Shamim A. Sahibzada is Chief, Training Programme, at the Pakistan Institute of Development Economics, Islamabad. 
individuals, and the welfare of the farming community. Before going into such a discussion, it seems important to look into the trends of subsidies on various inputs beginning with 1979-80. While this has been done in the form of Table 1, the relevant discussion follows.

Many conclusions follow from the data in Table 1 . First, the explicit or budgetary subsidies were more important than the implicit or concealed subsidies during the early Eighties, but almost vanished from the scene by 1994-95. This, in other words, implies that the withdrawal of explicit subsidies was the main target of government policy with little or no emphasis on implicit subsidies. As a result, explicit subsidies, despite fluctuations, fell consistently; but implicit subsidies continued to witness positive growth rates over the period under consideration. Second, fertiliser subsidy accounted almost entirely for the explicit subsidies. In the case of implicit subsidies, irrigation water was responsible for the lion's share of almost 60 percent, followed by the shares of institutional credit and electricity. Third, although much is made of the agricultural input subsidies in most of the government meetings and public forums, they hardly exceeded Rs 2-3 billion for most of the period, and never exceeded Rs 8 billion a year. Finally, as a percentage of budgetary expenditure, total subsidies on agricultural inputs fell from nearly 10 percent in 1979-80 to 1.54 percent in 1994-95.

It should be noted, however, that most of the calculations of subsidies on agricultural inputs involve the differences between expenditures and receipts from the supply of a given input. Although it is commonly assumed in most studies on input subsidies that they accrue to agriculture, it would be true under such assumptions as correct reporting of government receipts and expenditures on inputs, efficient operation of production and distribution systems of agricultural inputs, and absence of externalities and additional costs to producers beyond what appeared in government budgets. As the actual conditions in Pakistan deviate considerably from the above ideal situations, it is but natural to speculate that a significant proportion of the calculated subsidies may not accrue to the farm sector.

For example, the budgetary expenditure and receipts may not reflect the benefits and costs of irrigation water to the farmers. There is always over-reporting of expenditures and under-reporting of irrigation receipts. Although no estimates of the degree of escalation of expenditure in Pakistan are readily available, the Indian experience with a similar irrigation system as that in Pakistan suggests that the actual irrigation expenditure may be only half of that reported in the government budgets [Wade (1982) and Rao (1984)]. Furthermore, the provincial irrigation departments in Pakistan are overstaffed to the extent of 50 percent [Wolf (1986)] and would be responsible for excessive expenditure. Apart from overstaffing, the recent surges in irrigation expenditure must be attributed to growing illicit practices, steep increases in the maintenance costs of public tubewells, and multiple increases in the salaries and allowances of government employees. While the governments tend to treat any increase 
Table 1

Agricultural Input Subsidies by Inputs from 1979-80 to 1994-95

\begin{tabular}{|c|c|c|c|c|c|c|c|c|c|c|c|}
\hline \multirow[b]{2}{*}{ Year } & \multicolumn{4}{|c|}{ Budgetary or Explicit Subsidies } & \multirow[b]{2}{*}{$\begin{array}{l}\text { Sub- } \\
\text { total }\end{array}$} & \multicolumn{4}{|c|}{ Concealed or Implicit Subsidies } & \multirow{2}{*}{$\begin{array}{c}\text { Total } \\
\text { Implicit } \\
\text { and Exp- } \\
\text { licit }\end{array}$} & \multirow{2}{*}{$\begin{array}{l}\text { Total Subsidies } \\
\text { as Percentage of } \\
\text { Consolidated } \\
\text { Govt. Budget }\end{array}$} \\
\hline & $\begin{array}{l}\text { Fertili- } \\
\text { ser }\end{array}$ & $\begin{array}{l}\text { Tube- } \\
\text { well }\end{array}$ & $\begin{array}{l}\text { Plant } \\
\text { Protec- } \\
\text { tion }\end{array}$ & $\begin{array}{l}\text { Seed } \\
\text { and } \\
\text { Others }\end{array}$ & & $\begin{array}{l}\text { Irriga- } \\
\text { tion } \\
\text { Water }\end{array}$ & Credit & $\begin{array}{l}\text { Electri- } \\
\text { city }\end{array}$ & $\begin{array}{c}\text { Sub- } \\
\text { total } \\
\text { Subsidies }\end{array}$ & & \\
\hline $1979-80$ & 2455 & 22 & 218 & 29 & 2724 & 297 & 116 & -16 & 397 & 3121 & 9.31 \\
\hline $1980-81$ & 2448 & 20 & - & - & 2468 & 338 & 180 & -88 & 430 & 2898 & 7.19 \\
\hline 1981-82 & 1750 & 24 & - & - & 1774 & 416 & 265 & -11 & 670 & 2444 & 5.59 \\
\hline $1982-83$ & 1948 & 24 & - & - & 1972 & 437 & 349 & -100 & 686 & 2658 & 4.69 \\
\hline $1983-84$ & 1466 & - & - & - & 1466 & 661 & 524 & -153 & 1032 & 2498 & 3.47 \\
\hline $1984-85$ & 1501 & - & - & - & 1500 & 828 & 543 & 103 & 1474 & 2974 & 3.55 \\
\hline $1985-86$ & 2409 & 16 & - & - & 2425 & 1005 & 448 & 16 & 1469 & 3894 & 4.10 \\
\hline 1986-87 & 1284 & - & - & - & 1284 & 1234 & 551 & 375 & 2160 & 3444 & 2.83 \\
\hline $1987-88$ & 1995 & 15 & - & - & 2010 & 1352 & 785 & 1112 & 3249 & 5259 & 4.07 \\
\hline 1988-89 & 2415 & - & - & - & 2415 & 1154 & 1009 & 1139 & 3302 & 5720 & 3.74 \\
\hline $1989-90$ & 1257 & - & - & - & 1257 & 1028 & 1207 & 1380 & 3615 & 4872 & 2.89 \\
\hline $1990-91$ & 1248 & - & - & - & 1248 & 1545 & 1526 & 1625 & 4696 & 6220 & 3.11 \\
\hline 1991-92 & 1191 & - & - & - & 1149 & 2701 & 1744 & 1796 & 6321 & 7512 & 3.28 \\
\hline $1992-93$ & 810 & - & - & - & 810 & 3111 & 1993 & 1724 & 6829 & 7639 & 2.80 \\
\hline $1993-94$ & 805 & - & - & - & 805 & 2565 & 1980 & 330 & 4875 & 5680 & 1.83 \\
\hline 1994-95 & 79 & - & - & - & 79 & 2938 & 1986 & 330 & 5254 & 5333 & 1.54 \\
\hline
\end{tabular}

Source: [Government of Pakistan (1994) and (1994a)], Provincial Budgets and Qureshi (1993) and a communication from WAPDA, Lahore for electricity subsidy from 1988-89 onward. 
in expenditure as a subsidy to farmers, it is questionable whether the financing of such expenditures should be the responsibility of the farm sector.

The under-reporting of receipts follows from two sources. First, water rates were under-assessed by irrigation officials to the extent of 10 percent in the Punjab and the NWFP, 30 percent in Sindh, and 60 percent in Balochistan [Government of Pakistan (1990)], and so were irrigation receipts. Second, because of widespread corruption among irrigation officials, farmers are charged illegal gratifications which do not appear anywhere in the budgets and accrue directly to irrigation staff [Ilyas (1994); Chaudhry, Majid and Chaudhry (1993); and Wolf (1986)]. Due to these reasons, it is doubtful if the irrigation water in Pakistan was at all subsidised. Like irrigation, the supply of electricity also suffers from the common distortions prevalent in Pakistan's irrigation system. In the case of fertilisers, the sub-standard production, underbagging, and blackmarketing [Government of Pakistan (1993) and Government of Punjab (1991)] are common problems and leave little for the farmers to benefit from subsidies. Similar problems characterise the agricultural credit markets as the farmers incur more charges on getting access to credit than the savings from low interest rates. Accounting for some of the above distortions in input markets, the comparisons of effective and nominal protection coefficients for agricultural crops in Pakistan [Appleyard (1987) and Longmire and Debord (1993)] reveal that agricultural inputs in aggregate received no subsidies but were implicitly taxed to the extent of 5-10 percent throughout the Eighties.

\section{EFFECTS OF THE WITHDRAWAL OF SUBSIDIES}

The withdrawal of subsidies from agricultural inputs could affect the trends of national economy in various ways. In accordance with the norms of theory, the removal of input subsidy by ending under-pricing of inputs should ensure greater efficiency of input use in agriculture [Government of Pakistan (1985)]. It was also argued at least in Pakistan that the subsidy bills have become huge and they impinge on alternative investment avenues capable of yielding better returns to farmers and the national economy [Government of Pakistan (1980)]. A further point is sometimes scored on the ground that subsidy removal was essential to restore competition in major input markets by privatisation, deregulation, and denationalisation.

While the above arguments carry considerable weight on theoretical grounds, it is difficult to uphold them in real world situations especially in a less developed country like Pakistan. For one thing, the use of modern inputs in Pakistan is much below the recommended levels and raising the prices of inputs would push their use downwards and add to the inefficiency of input use. As most subsidies are absorbed by the inefficiency of the production and distribution systems, mere increases in input prices are also the means of supporting inefficiencies outside the agricultural 
sector. It, therefore, follows that simple increases in input prices offer no solution and might be associated with adverse effects on positive developments in agriculture in the following important ways.

As a first step, the withdrawal of subsidy and the consequent increases in input prices without any compensating changes in commodity prices tend to reduce profitability in agriculture and induce adverse effects on the growth of agricultural output. The experience with the withdrawal of subsidies in Pakistan has amply demonstrated that it was accompanied by falling or even negative rates of profits on the cultivation of major agricultural crops [Afzal et al. (1993) and Ahmad and Chaudhry (1987)]. If this were to happen again (which is the most likely situation in view of political resistance to increases in food prices), a slow-down or negative trend in the growth of agricultural output might be expected. Although it may be a mere coincidence, the growth of crop production tapered off to stagnation between 1979-80 and 1993-94 particularly during the last four years in response to steeper price increases in major agricultural inputs over the same period [Government of Pakistan (1994a)]. Apart from its adverse effects on output, a persistent low profitability of agriculture might induce capital flight from agriculture and reduce savings and investment.

The adverse impact of subsidy removal on macro-economic aggregates is shared disproportionately by the small and marginal farmers. For example, small farmers are likely to suffer the greatest losses of production after the upward revision of fertiliser prices. Being risk-averse and financially poor, small farmers take a much longer time to adjust to price shocks and to reduce fertiliser use to a greater extent relative to other farmers. Two studies have cited the relevant empirical evidence. For example, Naqvi, Khan, and Chaudhry (1989) have demonstrated that small farmers compared favourably with large farmers in the use of fertiliser during the late Seventies but lagged behind large farmers during 1980-81 when fertiliser prices were raised by nearly 50 percent. The same phenomenon was observed by the NDFC (1994). In response to a fertiliser price increase varying between 11 and 44 percent for various types of fertilisers, small farmers reduced their fertiliser input by 54 percent as against 13 percent by the large farmers. As a consequence, fertiliser application rate for the small farmers went down from 1.72 bags of $50 \mathrm{~kg}$ weight in 1993 to 0.79 bags in 1994. By contrast, large farmers reduced their input from 1.90 bags in 1993 to 1.65 bags in 1994 [NFDC (1994)]. Similarly, the impact of the upward revision of intensity-based water rates on small farmers would be 2-3 times that on large farmers [Chaudhry, Majid, and Chaudhry (1993); Ilyas (1994)].

Being most likely to take up farm and non-farm jobs, small farmers would be the first ones to be affected by the rising rates of unemployment. Most of the small and marginal farmers would be hit hard by the rapidly rising rates of inflation because of the regressive impact of inflation. 
Last, but not the least, the removal of fertiliser subsidy (because of its excessive burden on the incomes of small farmers) would reduce their abysmally low rates of savings and further undermine their meager investment potential. In a nutshell, the rising fertiliser prices do not only impinge on the current incomes of the small farmers [Ahmed (1981)] but also reduce their prospects for earning a respectable income in the future. What should be done and how their prospects of earning reasonable incomes in the future could be brightened is a question that would be answered in the final section of this paper.

The situation outside the agriculture sector should be no different from that in agriculture. While cost-based or averted-cost-based pricing system of inputs encourages malpractices and supports inefficient production and distribution systems, many poor people continue to suffer from the adverse trends in production, employment, and prices of essential commodities.

\section{POLICY RECOMMENDATIONS}

In view of the many adverse effects on macro-economic aggregates, and particularly on the welfare of the vulnerable groups, the policy redirections must minimise costs of subsidy withdrawal by promoting an efficiency-based system of input pricing. To accomplish this, the following discussion points to some of the policy changes required in various input markets.

It may be noted that most of the agricultural input markets are still in their infancy in Pakistan and suffer from even greater fundamental problems than the commodity markets. For example, they are typically characterised by monopoly positions of one kind or another; quality is no consideration and almost any product is saleable at the asking price. These problems are particularly acute in the modern input markets such as those dealing in seeds, insecticides, and fertilisers, with only a few exceptions in the irrigation water and credit markets.

In order to take a start, seeds supplied by seed agencies are admixtures of all varieties and have doubtful viability. This being so, there is hardly any justification for premium prices for seed. Rather than emphasising the mushroom growth of seed agencies and the quantities of seed marketed, quality should be the main consideration with clear labels of the seed agency testifying to the variety of seed, its viability, and the date when the seed was tested for germination. Any inconsistent results at the farm level should be punishable by fines recovering all costs associated with seed purchases, preparatory tillage operations, and efforts foregone in acquiring seed-for reimbursement to the farmers affected by the malpractice.

A similar policy action may also be suggested to check the production and marketing of sub-standard, fictitious, and underbagged fertilisers and insecticides. To break up the monopoly of registered dealers and to promote competition, the 
government should withdraw from the production, trade, and distribution of fertilisers in favour of free sales in the open market by interested parties and individuals.

In the case of irrigation water, the need for equitable distribution of water among outlets and canals, elimination of overstaffing, and precise alignment of the water rate assessment base with the water supply base can hardly be overemphasised. While all three recommendations would be consistent with stepped-up water use or cost efficiencies, the latter should also protect the small farmers from the onerous burdens of current intensity-borne water rates. The unlimited powers of irrigation officers should be carefully balanced by granting some powers to irrigation associations of the farmers to wipe out corruption from the irrigation departments. The credit market needs to be made more competitive with the same terms and conditions for agricultural credit as those for other loans. While demand-creation strategies lead to much waste, effective supply management with a view to reducing costs of loans to government should serve as the basis of future credit strategy in agriculture.

In a nutshell, the emphasis of the government policy should be to minimise costs of its programmes, ensure efficiency of resource use in agriculture, and, so far as possible, discourage corruption and unnecessary intervention in agriculture. Although the private sector can deliver many services to agriculture, its unbridled growth, based on excessive profits and without specification of the rules of the game, would be equally undesirable.

\section{SUMMARY AND CONCLUSIONS}

The major aim of the present study has been to look into the problems of subsidisation of agricultural inputs and its removal in Pakistan. It has been argued that Pakistan has had a history of agricultural input subsidies beginning with the 1950s. Despite the commitment to their removal, subsidies on agricultural inputs have tended to persist. If they were open subsidies in the 1950s and 1960s, they have become increasingly implicit in the recent years. It is for this reason that many of them may not accrue to the farm sector but are eaten up by the inefficiencies of the production and distribution systems. It should be noted that input price increases as a means of eliminating subsidies tend to add to the inefficiency of input use in agriculture and also provide support to the inefficient production and distribution systems of inputs outside the agriculture sector. Unbridled increases in input prices are particularly harmful to the cause of small farmers, income distribution, and rural poverty. The strategy of removal of subsidies should, therefore, be based on cost savings and low prices of inputs in agriculture.

\section{REFERENCES}

Afzal, Muhammad et al. (1993) Support Price System in Pakistan. Pakistan Journal of Agricultural Economics 2:1. 
Ahmad, Bashir, and M. Ali Chaudhry (1987) Profitability of Pakistan’s Agriculture. The Pakistan Development Review 27: 4 457-470.

Ahmad, Mushtaq (1981) Direct Government Subsidies in Pakistan. The Journal of Development Studies 4.

Appleyard, Dennis R. (1987) Report on Comparative Advantage. Islamabad: Agricultural Prices Commission. (APCom Series No. 61.)

Aresvik, Odd Var (1967) Strategy and Outlook for Agricultural Development in West Pakistan. Unpublished paper, prepared for the "Symposium on Strategy of Agricultural Planning in Developing Countries," at the All-Pakistan Science Conference held at the University of Sindh, Jamshoro.

Chaudhry, M. Ghaffar (1982) Green Revolution and Redistribution of Rural Incomes: Pakistan's Experience. The Pakistan Development Review 21:3 173-205.

Chaudhry, M. Ghaffar, Syed Abdul Majid, and Ghulam Mustafa Chaudhry (1993) The Policy of Irrigation Water Pricing in Pakistan: Aims, Assessment and Needed Redirections. The Pakistan Development Review 32:4 809-821.

Ilyas, Muhammad (1994) Water Markets Plan to Harm Small Farmers. The Daily Dawn. (Economic and Business Review) April 9-15.

Kuhnen, Frithjof (1989) The Agrarian Sector in Pakistan's Development Process: Historical Evidence and Implications for Policy and Theory. The Pakistan Development Review 28:4 509-528.

Longmire, Jim, and Pascale Debord (1993) Agricultural Pricing and Comparative Advantage in Pakistan: An Update to 1991-92. Report prepared for the South Asia Division of the World Bank, Washington, D. C.

Naqvi, Syed Nawab Haider, M. H. Khan, and M. Ghaffar Chaudhry (1989) Structural Change in Pakistan's Agriculture Islamabad: Pakistan Institute of Development Economics.

NDFC-National Fertiliser Development Centre (1994) Spot-checking of Fertiliser Sale and Price Position During Kharif (May-June) 1994. Islamabad.

Niaz, Shafi (1984) Fertiliser Pricing System in Pakistan. Islamabad: Agricultural Prices Commission. (APCom Series No. 23.)

Pakistan, Government of (1980) National Agricultural Price. Islamabad: Ministry of Food, Agriculture and Coopertatives. Food and Agriculture Division.

Pakistan, Government of (1985) Pakistan Economic Survey 1984-85. Islamabad: Finance Division.

Pakistan, Government of (1990) Nationwide Study for Improving [the] Procedure for Assessment and Collection of Water Charges and Drainage Cess 1:3 Islamabad: Ministry of Water and Power.

Pakistan, Government of (1990a) Pakistan Economic Survey 1989-90. Islamabad: Finance Division. 
Pakistan, Government of (1993) Report of Prime Minister's Task Force on Agriculture. Islamabad: Revenue Division.

Pakistan, Government of (1994) Economic Survey 1993-94. Islamabad: Finance Division.

Pakistan, Government of (1994a) Statistical Supplement 1993-94: Economic Survey. Islamabad: Finance Division.

Punjab, Government of (1991) Report of the Input-Output Price Review Committee. Lahore: Finance Department.

Qureshi, Sarfraz Khan (1993) Fiscal Impact of Government Interventions in Pakistan. In Agricultural Pricing Study (Annexures):Draft Preliminary Report (1993). Asianics Agro-Dev. International and John Mellor Associates.

Rao, P. K. (1984) Introduction to Discussion on Water Rates: Comments on Cost Recovery and Irrigation Water Pricing. London: (ODI Network Paper 10F.)

Wade, Robert (1982) The System of Administrative and Political Corruption: Canal Irrigation in South Asia. Journal of Development Studies 18:3.

Wolf, James M. (1986) Cost and Financing of Irrigation System Operations and Maintenance in Pakistan. In Douglas J. Merry and James M. Wolf (eds) Irrigation Management in Pakistan. Colombo, International Irrigation Management Institute. World Bank (1986) Pakistan Economic and Social Development Prospects. Washington D. C.: (Report No. 5962-PAK.) 


\section{Comments}

It is an interesting paper discussing an important but controversial subject. The authors are to be complimented for forcefully articulating some of the well-known adverse effects of removing the input subsidies. Nevertheless, their arguments appear to be lopsided as they have chosen to ignore the realities on the ground.

Two types of input subsides in the farm sector, i.e., budgetary/explicit subsidies and concealed/implicit subsidies, have been addressed. The budgetary subsidies included in the analysis relate to fertilisers, pesticides, seed, and tubewells, while the implicit subsidies on irrigation, credit, and electricity are discussed. The period of analysis covered in the paper spans from 1979-80 onward, coinciding with the period when the tide started turning against the input subsidies.

The subsidy on fertilisers, as the authors quote authoritative sources, was introduced to popularise their use. It is quite well-known, and also borne out by empirical studies, that the use of fertilisers by small as well as large farmers, owner as well as tenant, has become quite popular and made a significant contribution to agricultural production in the country. But supply bottlenecks and shortages at critical times, resulting in black-marketing of the input, are applying brakes on its use. In periods of short supply and black-marketing, the small farmers, in whose name the inputs are generally subsidised, lacking the requisite clout, are the worst sufferers. Under such circumstances subsidisation of the input prices may not serve the purpose. Moreover, it is not sure whether the budgetary subsidies actually benefited the farmers or the oligopolies dominating the fertiliser marketing and distribution, as the authors did not resort to an 'economic' analysis of the subsidy issue.

The authors have forcefully highlighted the adverse effects of the removal of subsidy on fertilisers on their use, but the arguments are couched in qualitative terms. Had the authors supported their arguments with empirical analysis of the output losses resulting from lower fertiliser use, this should have added an important dimension to the analysis. Similarly, the authors have ignored the consequences of the removal of subsidies on fertiliser, an important input accounting for 10-15 percent of the cost of production of major crops, for the export competitiveness of our agriculture.

Now, when the much talked about subsidy on fertilisers has been removed, I hope the attention would shift to (i) ensuring adequate supplies, (ii) fine-tuning methods and timing of their use, (iii) judicious mix of nutrients, and (iv) use of complementary inputs and agronomic practices to make the best use of resources. The removal of subsidies on chemicals may also have a positive fall-out for the 
environment if it is helpful in correcting the imbalance and indiscriminate use of various agro-chemicals.

Although the government in recent years has increased the minimum prices of the output to offset the impact of increase in input prices on farmer's cost of production and their well-being, yet the real impetus in this direction is likely to come from the removal of export taxes, increasing the role of the private sector in the marketing of output, and the removal of restrictions on commodity movements.

Regarding the case of water, which has dominated the implicit subsidies, I agree with the authors that a large part of this is due to the malpractices rampant in the irrigation department. The lion's share of the implicit subsidy on credit has been usurped by the big landlords. Huge distribution losses of WAPDA may be largely responsible for the so-called implicit subsidy on electricity. Power tariff for tubewells has increased manifold in recent years, hitting hard the economics of tubewell irrigation. In the wake of the exorbitant hike in the rates of power, farmers are reported to be switching to other sources of energy for tubewells.

Things on the water front have gone much farther than just curtailing the implicit subsidies and the increase in water rates. Donors have been pressing for privatising the irrigation network, selling water to the highest bidder based on demand. The situation is fraught with many problems. I wish the authors had not chosen to remain silent on this vital issue.

I agree with the policy prescription of removing corruption and malpractices from input markets and the irrigation department, as argued by the authors, but it is easier said than done. Notwithstanding the removal of subsidies on fertilisers, their use has continued to increase, albeit at a slower rate. Contrary to the authors' assertion, agricultural output of major crops has expanded during the last 10 years. For example, the output of cotton, sugarcane, wheat, and rice, four major crops accounting for 63 percent of the cropped area, is estimated to have increased at the annual rates of 3.5, 4.5, 3.3, and 1 percent, respectively. The setback to cotton during the last three years had its origin elsewhere and may not be attributed to the removal of fertiliser subsidy. Pakistan is endowed with some of the best farm resources, which, however, have not been managed well to realise their potential.

In the changing circumstances when de-regulation, privatisation, and reliance on market forces have become the keywords in the donors' kit and professional jargon, we ought to be careful that factor markets are not dominated by vested interest and manufacturers do not monopolise the trading and distribution, as was the case with fertilisers when manufacturers were also the distributors and importers and short supply served their interest rather well. To ensure fair competition, there is a need to ensure free entry as well as exit from the market, as well as provision of adequate infrastructure. To forestall the undesirable side-effects of the abovementioned policy changes, which are here to stay, it is imperative to have indigenous 
institutional capacity to continuously monitor the situation and analyse the impact of policy changes on various sectors of the economy.

Agricultural Prices Commission,

Abdul Salam

Islamabad. 